\title{
Service of Documents Instituting Civil Proceedings
}

\author{
MÁTYÁs KAPA*
}

\begin{abstract}
The following article presents the importance of the service of documents instituting civil proceedings as well as the relevant Hungarian and European Union legislation. The author covers the formal requirements of the service of documents, the claims brought against defendants, the subsequent stages of proceedings and the issue of providing adequate information on potential legal consequences.

Keywords: service of process, service of documents instituting civil proceedings, due notice, due information about the claim, European civil procedure.
\end{abstract}

\section{INTRODUCTION}

The service of documents is very important in a civil procedure, especially because several legal effects connect to the due delivery of documents. From the viewpoint of the rule of law, the service of the statement of claim, or other documents instituting civil proceedings, has a special importance. In my paper I will focus on the appropriate forms of service of document instituting civil proceedings.

In regulating the service of documents instituting civil proceedings, the legislator has to take into account a number of different considerations. ${ }^{1}$ In accordance with the requirement of legal certainty, it has to be possible to prove $i$ ) that the service of documents has indeed been done, ii) the date of the service of documents and iii) who has been served with the documents. The implementation of the right to a fair trial within a reasonable time as enshrined in Article 6 of the European Convention on Human Rights necessitates the prompt service of documents. On the other hand, such service should enable the defendant to duly prepare for his defense following the receipt of judicial documents. ${ }^{2}$ This issue has to be analysed in a broader context: importance has to be attached not only to the method of the service of documents instituting proceedings, but to the content of the documents served as well. The content of the documents served is of particular significance, since they provide the defendant with adequate information about the claim brought against him, the subsequent stages of proceedings and potential legal consequences, on the basis of which the defendant is able to decide on whether he should contest the claim and on what kind of defense tactics he should use. With regard to the above, I will hereunder address two issues: how should the documents instituting civil proceedings be served on the defendant and what should these documents contain.

Nevertheless, before starting to present the topic, I should narrow down my field of examination. From this year in Hungary, in most of the civil procedures electronic communication become obligatory. In the most cases the court shall deliver judicial documents to parties maintaining electronic communication. Despite in this paper I won't write about the electronic communication. The main cause of this decision, that for the

* attorney, senior lecturer, ELTE, college professor, Wekerle Business School. E-mail: kapa. matyas@ajk.elte.hu

1 Kengyel and Harsági (2009) 283.

2 See Lindacher (2000): Fortschritt, Auslegungsbedarf, Problemusblendung. ZZP, 2001, 180., and Stadler. (2001), 515. 
service of the statement of claim we don't use the electronic communication. The court shall deliver to the defendant any statement of claim that was submitted by electronic means in the form of a paper-based document.

\section{HUNGARIAN REGULATION}

In the year 2016, the Hungarian Parliament seeks to adopt a new Code of Civil Procedure, which, however, does not envisage any significant change to the existing rules on the service of documents instituting civil proceedings.

\subsection{The formal requirements of the service of documents}

The draft version of the new Code of Civil Procedure largely reproduces the currently applicable rules on the service of documents, and proposes only some small clarifications.

The Hungarian regulation acknowledges the service of the documents instituting civil proceedings in three different forms, and there is a hierarchy among these forms:

a) Personal service or substitute service with proof of receipt

There can be three different methods:

- Service by the postal service provider

- Service by Bailiff

- Personal service in the court office

b) Service by application of the legal fiction of service

c) Service of Process by Public Notification

\subsubsection{Personal service or substitute service with proof of receipt}

\subsubsection{General provisions}

In general, judicial documents shall be served personally to the addressee, or to a substitute recipient. If the party has an authorized representative for handling the case, judicial documents shall be delivered to the authorized representative instead of the party. If the party is legally incapacitated, has no authorized representative for handling the case, judicial documents shall be delivered to the legal representative. If the party is other than a natural person and has no authorized representative for handling the case, judicial documents shall be delivered to the registered office of the party. If the service to the registered office of the party other than a natural person fails, a delivery attempt shall be made also to his legal representative. The provision concerning the service of process upon an authorized representative shall not apply to writs of summons ordering the party or the party's legal representative to appear in person.

\subsubsection{Agent for Service of Process}

Any plaintiff who has no permanent or temporary residence, or registered office in Hungary, and has no authorized representative with a permanent residence or registered office in Hungary for arguing the case on his behalf, shall indicate the name and address of his agent for service of process at the time of submission of the statement of claim. The party's contract with the agent for service of process shall be attached to the statement of claim. If the plaintiff does not fulfil this obligation, the court shall instruct the plaintiff - by setting an appropriate time limit - to report the name and address of his agent for service of process and to submit the contract with the agent. 
If the defendant has no permanent residence or registered office in Hungary, and has no authorized representative with a permanent residence or registered office in Hungary for arguing the case on his behalf, the court shall instruct such defendant - by setting an appropriate time limit - at the time of reception of the statement of claim to delegate an agent for service of process. The defendant shall report the name and address of his agent for service of process before the deadline set by the court, and shall submit the contract with the agent.

If the party fails to delegate an agent, or fails to delegate a replacement agent for service of process upon termination of the previous service contract, or if documents cannot be delivered to the agent for service of process, the documents shall be delivered by way of public notification. This provision shall not apply to the service the statement of claim to the defendant.

The agent for service of process may be a natural or legal person with a permanent residence or registered office in Hungary, such as, in particular, an attorney or a law firm. The agent for service of process shall be responsible for collecting the documents of the proceedings addressed to his principal, and to forward these documents to the principal. Where any official document is delivered to the agent for service of process on the party's behalf, it shall be presumed that the party has knowledge of them on the fifteenth day after they are delivered to the agent in due process. The court shall notify the non-resident party of the rules relating to the agent for service of process.

The rules related to the agent for service of process shall not apply in the case of a party having a permanent or temporary residence or registered office within the European Union.

2.1.1.3. Methods of personal service or substitute service with proof of receipt

a) Service by the postal service provider

In general, judicial documents shall be served by way of the postal service provider. Service shall be implemented with return receipt, in accordance with the provisions on the service of official documents.

\section{b) Service by Bailiff}

If a statement of claim or other document instituting civil proceedings attempted to be served by postal service from the declared address of the addressee with temporary or permanent residence or registered office in Hungary returns to the court marked:

a) 'address not identifiable',

b) 'recipient unknown',

c) 'recipient moved',

d) 'service impeded',

the service of the document shall be attempted, concerning the service of judicial documents by bailiff.

The application for the service of a judicial document by bailiff shall be submitted to the court. The requesting party is obliged to pay the fee for the bailiff. The deadline beginning with the service of judicial document shall be counted from the date when the service of judicial document by bailiff is executed effectively by law.

c) Personal service in the court office

The addressee may collect a document that was addressed to him in the court offices, subject to positive proof of identification. 


\subsubsection{Legal Fiction of Service}

\subsubsection{Cases of Legal Fiction of Service}

Judicial documents served by way of the postal service shall be considered served on the day of attempted delivery if the addressee refused to accept it. If service failed because the addressee didn't make any effort to receive the document (for example it was returned to the court marked 'unclaimed'), the document shall be considered served on the fifth working day following the day of the second attempted postal delivery. These cases result the Legal Fiction of Service.

In connection with the service of a statement of claim or other document instituting civil proceedings, the court shall notify the parties concerning the use of legal fiction of service within eight working days by way of the postal service. In the notice the court informs the parties of the relevant rules concerning the objection against the legal fiction of service, and in case of a statement of claim, also of the effects of commencement of the procedure. The notice shall have enclosed the official document underlying the court's declaration of service of process.

\subsubsection{Objection against the Legal Fiction of Service}

The addressee may lodge an objection against the legal fiction of service within fifteen days of gaining knowledge of the effective date of service of process at the court. No petition may be submitted after three months have elapsed from the effective date of the legal fiction of service. If the effect of the legal fiction of service is connected to the service of the document instituting the proceedings, the party may submit the objection in the course of the proceedings within fifteen days of gaining knowledge of the effective date of service of process.

An objection against the legal fiction of service may be submitted alleging that the addressee was unable to accept the official document:

a) stating that service was carried out in violation of the provisions of specific other legislation on the service of official documents, or it was illegitimate for other reasons, or

b) stating that he was unable to collect the document for other reasons, but through no fault of his own (for example he didn't know anything about the attempted service). For this second reason, an objection against the legal fiction of service may only be submitted by natural persons.

The addressee may not submit an objection against the legal fiction of service with reference to that the judicial document was delivered to the addressee's declared temporary or permanent residence or registered office in public registers. The petition shall contain the facts and other evidence to demonstrate the alleged infringement in the service of process or to demonstrate that the addressee is not at fault. If the petition is submitted in delay, it shall be refused without examining the merits. The petition shall be decided by the court. Before adopting a decision the court shall interview the addressee and the parties. The petition shall be assessed fairly. If the court decides in favor of the petition, the legal consequences related to the legal fiction of service shall not apply and the service of process, and the measures and actions already carried out, shall be repeated to the extent requested by the party.

\subsubsection{Service of Process by Public Notification}

2.1.3.1. Cases of Service of Process by Public Notification, Terms and Conditions, A process shall be served by way of public notification:

a) if the party cannot be located and the judicial document cannot be sent to the party in an electronic way, 
b) if the party resides in a State where there is no legal assistance available as to service

c) if the court cannot deliver to the plaintiff the order refusing the Statement of Claim

d) if the party fails to delegate an agent for service of process, or if documents cannot be delivered to the agent for service of process,

e) if the service of process by public notification has a place and role to unknown heritor

f) or if service is hindered by insurmountable obstacles.

The court may order service of process by way of public notice only if so requested by the party and only if any proof concerning the underlying reason is produced.

\subsubsection{Legal Consequences of infringment in Service of Process by Public Notification}

The service of process by public notice ordered in the absence of legal conditions and the following procedure shall be declared null and void, if not approved by the opposing party (upon whom the judicial document is served by way of public notice). If the facts presented by the party turn out to be untrue, of which the party had been aware, or should have been aware given reasonable care, the party shall be ordered to cover all applicable costs and to pay a financial penalty as well.

\subsubsection{Ways of service of process by public notice}

The public notice shall be posted for fifteen days on the bulletin board of the court, and on the bulletin board of the mayor's office of the community where the last known residence of the party is located, and shall be published on the central website of the judiciary as well as sent to the e-mail address of the party.

If the party resides in a State where there is no legal assistance available as to service, however, connection through postal service is available, the notice shall be dispatched to the party's address in that State. Where service of process by public notification is carried out on the basis of rules related to the agent for service of process, and the party resides in a State with which connection through postal service is available, the notification shall be dispatched to the party's address in that State as well.

If a statement of claim is to be served to the defendant by way of public notification, the court shall appoint a guardian ad litem to the defendant, and shall have the statement of claim delivered to this guardian ad litem as well - provided that the costs of guardian ad litem is advanced by the plaintiff.

If the conditions for service of process by public notice occur only after the regular service of the statement of claim to the defendant, a guardian ad litem shall not be appointed to the defendant.

Costs of service of process by public notice shall be advanced by the party that has requested such public notification. In the case of service of process by public notice, the notice shall be considered served on the fifteenth day following the time when posted on the court's bulletin board.

\subsection{Provision of adequate information}

Hungarian law stipulates that the defendant shall be served with the plaintiff's statement of claims not later than the date of service of the writ of summons for the first court hearing on him and shall be informed inter alia about the legal consequences of failing to attend the court's hearing, the different forms of legal aid and the possibility of being represented in court. 
The court shall deliver the statement of claim to the parties together with a writ of summons ordering them to appear before the court on this date. Accordingly the writ of summons for the first hearing shall have attached a copy of the statement of claim, unless it was previously delivered. The statement of claim includes the court of competence; the names and addresses of the parties and their counsels, and their status in the action; the cause of action, including a description of the circumstances invoked as the basis of the claim and a description of the evidence supporting the claim; the grounds for competence and jurisdiction of the court; a plea for court decision (pleading).

The above shows that, on the basis of the relevant Hungarian rules, the document instituting civil proceedings provides the defendant with sufficient information to ponder on the well-foundedness of the claim brought against him and decide on what procedural steps to take.

\section{EUROPEAN REGULATION}

In the last 15 years the European Union has increased its legislative activity in the field of civil procedures. As a result of this, besides civil procedures regulated by the laws of each member state, independent, supranational procedures regulated by community law have appeared too. The legislation of the European Union is thus going into two completely different directions in the field of civil procedures. On the one hand, there are regulations that are meant to address specific problems of national but for some reason cross-border cases (jurisdiction, service of documents, taking of evidence, etc.). Other directives introduce European procedures that are fundamentally regulated by community law (European order for payment procedure and the European small claims procedure).

Following the above, the service of documents instituting civil proceedings has been brought to the attention of European regulators from two aspects. Firstly, Regulation no. $1393 / 2007 / \mathrm{EC}$ on the service in the Member States of judicial and extrajudicial documents in civil or commercial matters was adopted. Secondly, certain cross-border, sui generis and supranational procedures were set up to lay down minimum standards for the Member States that should apply to the service of documents and to the provision of adequate information to the defendant. Such standards are included in Regulation no. 805/2004/EC creating a European Enforcement Order for uncontested claims, Regulation no. 1896/2006/ EC creating a European order for payment procedure and Regulation no. 861/2007/EC establishing a European Small Claims Procedure.

\subsection{The formal requirements of the service of documents}

\subsubsection{The Service of Documents Regulation}

Regulation (EC) No 1393/2007 aims to put in place a fast, secure and standardised transmission procedure for judicial and extrajudicial documents in civil or commercial matters between parties located in different European Union (EU) countries.

EU countries designate the agencies that are responsible for transmitting and receiving documents. Each EU country also has a central body that is responsible for supplying information to the agencies, resolving any difficulties that may arise and forwarding requests for service by the transmitting agency to the relevant receiving agency in exceptional circumstances.

The applicant forwards documents to the transmitting agency and bears any costs of translation prior to transmitting the document. Documents must be transmitted directly and 
as soon as possible between the agencies by any appropriate means of transmission, as long as they are legible and faithful to the original. A request using the standard form as annexed to the regulation must be attached in one of the accepted languages that the EU countries indicate. The documents are exempt from legalisation or any equivalent formality.

The receiving agency should either serve the document itself or have it served within 1 month. If this is not possible, the receiving agency must inform the transmitting agency and continue to try to serve the document. Serving is done according to the law of the receiving EU country, or by a particular method, if this is requested by the transmitting agency and it conforms to the national law. When service has been carried out, a certificate of completion of the formalities involved must be completed in a language accepted by the EU country of origin and sent to the transmitting agency.

Documents may also be served directly by using registered post with a receipt or via the judicial officers, officials or other competent persons of the EU country addressed, if this is permitted by the country in question. The direct service of documents is allowed in Belgium, Finland, France, the Netherlands, Greece, Ireland, Spain, Cyprus and Malta, but is refused, for instance, in Hungary. ${ }^{3}$

In exceptional circumstances, documents may be forwarded to agencies of another EU country via consular or diplomatic channels.

The Regulation should not apply to service of a document on the party's authorised representative in the Member State where the proceedings are taking place regardless of the place of residence of that party. As regards the Hungarian Code of Civil Procedure, in case the party has an authorized representative for handling the case, judicial documents shall be delivered to the authorized representative instead of the party.

The receiving agency informs the addressee of their right to refuse the document, if it is not written in a language that he or she understands or in the official language of the EU country where service takes place. The refusal must take place at the time of service or by returning the document to the receiving agency within a week. ${ }^{4}$

\subsubsection{Other regulations}

Within the European Union's legislation, the first minimum standards on the service of documents and the provision of adequate information to the defendant (debtor) were introduced by Regulation no. 805/2004/EC creating a European Enforcement Order for uncontested claims.

\subsubsection{Minimum standards}

The development of these minimum standards were necessary because the measures protecting the debtor differ in many aspects from one Member State to another, especially as regards the rules of civil procedure on service. There is a major difference between the strict Austrian system and the rules applied by English law. According to the latter, service effected by way of a mere letter is sufficient. In Switzerland the person effecting service is not aware of the content of the instrument, while in France upon effecting service the debtor must be orally informed about its content with special regard to drawing attention to the legal effects. ${ }^{5}$ Likewise in most Member States fictitious methods of service, such as public

3 Kengyel and Harsági (2009) 294, 297.

$4<$ http://eur-lex.europa.eu/legal-content/EN-HU/TXT/?uri=URISERV:116031\&from=HU> accessed 6 June 2017.

5 Oberhammer (2006) 480. 
notification or transmission of the instrument to the prosecutor's office ('remise au parquet') in France, are provided as well pursuant to which the chance of providing the debtor with due information about the content of the instrument is rather low. ${ }^{6}$ The purpose of these minimum standards is 'to ensure that the debtor is informed about the court action against him, the requirements for his active participation in the proceedings to contest the claim and the consequences of his non-participation in sufficient time and in such a way as to enable him to arrange for his defence'?

The provisions the Regulation should not be regarded as having an imperative nature ${ }^{8}$, the fulfilment of which would be directly compulsory to the courts of the Member States. The explanation thereof lies in the lack of competence of the Community legislator. ${ }^{9}$ Pursuant to paragraph 19 of the Preamble the Regulation does not imply an obligation for the Member States to adapt their national legislation to the minimum procedural standards set out therein. Nevertheless the Regulation 'provides an incentive to that end by making available a more efficient and rapid enforceability of judgments in other Member States only if those minimum standards are met'. Some authors draw attention to this incongruence ${ }^{10}$ which they characterise as a 'strange and optional provision incorporated in the text of a Regulation'. However, non-compliance with the minimum standards shall result in refusal of certification as a European Enforcement Order. ${ }^{11}$

The minimum standards set out in the Regulation may be divided into two groups as regards the subject matter of the provision: one group contains the rules on service (Articles 13-15) and the other contains the rules on provision of information (Articles 16-17) ${ }^{12}$. The purpose of the minimum standards for the rules on service is to establish that service has been effected with either full certainty (Article 13) or a very high degree of likelihood (Article 14) $)^{13}$. The scope of application of this rule shall cover domestic and foreign service as well ${ }^{14}$.

\subsubsection{Service with proof of receipt by the debtor}

The Regulation distinguishes between principal and supplementary methods of service pursuant to the requirements to be complied with. ${ }^{15}$ The principal methods of service include the following: personal service attested by an acknowledgement of receipt, including the date of receipt, which is signed by the debtor; postal service or service by electronic means such as fax or e-mail, attested by an acknowledgement of receipt including the date of receipt, which is signed and returned by the debtor; where the competent person who effected the service attests the active or passive conduct of the debtor as regards receipt or refusal of the document.

${ }^{6}$ Kapa and Veress (2009) 192.

7 Paragraph 12 of the Preamble of the Regulation.

8 Wagner (2005) 1159.

9 Kropholler (2005) 603.

10 Péroz (2005) 650.

11 Kapa and Veress (2009) 193.

12 Storskrubb (2008) 158-60.

13 Paragraph 14 of the Preamble of the Regulation.

14 Kropholler (2005) 602.

15 Proposal for a Council regulation creating a European enforcement order for uncontested claims. COM (2002)159., 2002.04.18., 11. 
As regards the supplementary methods of service, the procedural documents are not served directly on the debtor but on persons who are living in the same household as the debtor or persons employed by the debtor or the representatives. Service may have been effected by depositing the document in the debtor's mailbox or at a post office or with competent public authorities, by post or by electronic means, since the debtor shall thereby be informed of the documents served by these means. The main difference between the two categories of method of service is that in case of a supplementary method of service the debtor shall not sign an acknowledgement of receipt. No hierarchy is established by the Regulation between these two categories therefore application of the supplementary methods of service is not limited to cases where personal service was unsuccessful. ${ }^{16}$ It can be established pursuant to the Preamble that the Regulation provides for the methods of service but leaves it to the decision of the Member States to adapt their national rules of procedure to the provisions of the Regulation.

The list of the methods of service included in Article 13,14 and 15 is exhaustive therefore other methods of service, such as public notification, are excluded from the scope of the Regulation and cannot be applied. All the methods of service listed in Articles 13 and 14 are characterised by either full certainty (Article 13) or a very high degree of likelihood (Article 14) that the document served has reached its addressee. No uniform Community procedural law shall be created by the regulation of the methods of service, rather those methods of service are emphasized which, according to the opinion of the legislator, mostly protect the rights of the debtor. ${ }^{17}$

The separation of the terms notification and communication ${ }^{18}$ have been criticized by certain authors, telling that communication is a method of notification, the latter being a hyperonym term that includes the foregoing. They recommend using the hyperonym term (i.e. notification), except in those cases where communication of the documents are effected by the competent persons.

As regards the object of service, Articles 13 and 14 adopt the provisions of Regulation (EC) No 44/2001 ${ }^{19}$ and refer to the same types of documents: the document instituting the proceedings or an equivalent document and also any summons to a court hearing.

Article 13(1)(a) provides for the conditions of personal notification to the debtor or service effected on him: within the meaning thereof the debtor shall sign the acknowledgement of receipt but it shall not be necessary to send it back, as required under paragraph (1)(c) and (d) of the Article at issue. This seems a logical solution since in case of personal service of the procedural document the debtor signs the acknowledgement of receipt which he then returns to the person effecting service. However, where service is attested by means of a simple private document or has not been effected by the competent person the conditions of point (a) shall not have been met, therefore the service shall not amount to personal service and provisions of point (c) shall apply. ${ }^{20}$

Article 13(1)(b) governs the case of service effected by the competent person. During the service the competent person effecting service shall have to attest that the debtor has received the document or refused to receive it without any legal justification and the date of

16 Stein (2004) 680.

17 Rauscher (2006) 1520.

18 Péroz (2005) 650.

19 In Article 24(2) of Regulation (EC) No 44/2001 on jurisdiction and recognition of judgments in civil and commercial matters. OJ L 012, 16/01/2001., 0001-0023.

${ }^{20}$ Kropholler (2005) 605. 
the service has to be indicated as well. The competent person effecting service can be any officer or any other person mandated in accordance with the laws of the Member States who is entitled to effect service. The competent person effecting service shall state in the appropriate document that the debtor has refused to receive the document without any legal justification. The Regulation does not specify what amounts to legitimate reasons. A case where the debtor is unfamiliar with the language of the document to be received can be such a reason for example. ${ }^{21}$ Furthermore, refusal can also be legitimate where the reason thereof relates to infringement of the provisions of the Member States on service of documents. ${ }^{22}$ The Regulation has also failed to regulate what happens when the addressee has refused to receive the document. No provision is available on whether the person effecting service should leave the document at the address for service. In case the debtor has refused to receive the document without any legal justification it shall be deemed to have been served. ${ }^{23}$

According to Article 13, upon postal service (see point (1)(c)) the debtor shall be obliged to sign and return the acknowledgement of receipt including the date of receipt. A simple letter shall not meet the requirements since the debtor signs no acknowledgement of receipt in that case. ${ }^{24}$ This statement applies to a registered letter as well where the debtor attests the receipt thereof but without returning the attestation to the sender. Notwithstanding the foregoing cases, a consignment sent with an acknowledgement of receipt is a postal service according to which the post shall return the acknowledgement of receipt including the signature of the addressee or its representative, attesting receipt of the consignment, to the sender.

Article 13(1)(5) stipulates that service of a document by electronic means such as fax or e-mail shall be deemed to have been served only where the acknowledgement of receipt including the date of receipt is returned by the debtor, according to the method in the previous paragraph. The method of returning the acknowledgement of receipt is not provided for. Neither is it clarified whether a response by electronic means is sufficient. According to certain authors ${ }^{25}$ where service can be effected by electronic means the same shall apply to the response. However, it shall be required that in case of a response sent by electronic means the acknowledgement of receipt should include the electronic signature of the debtor which shall also serve as proof of receipt and attest that the response indeed came from the debtor. Only an electronic signature/initials can substitute the signature of the debtor. ${ }^{26}$ Some have expressed as a counter-opinion that, in the case provided for by point (d), establishing who the electronic signature comes from can give rise to doubt since it is difficult to connect the signatory to the signature. They therefore suggested replacing this procedure with a procedure provided for by Article 14 until the technical development shall allow for identification of the electronic signature with a high degree of likelihood. ${ }^{27}$ A fax sent and initialed by the debtor shall meet the requirements set out in point (d).

The acknowledgement of receipt, which is mandatory in cases described in paragraph (1), is not only a means of proof of receipt but also a constitutive element of the service

21 Stellungnahme der Komission, KOM (2004) 90 endg., 5 zu Abänderung 9.

22 Kropholler (2005) 605.

23 Rauscher (2006) 1522.

24 Rauscher (2006) 1523.

25 Kropholler (2005) 605.

26 Rauscher (2006) 1523.

27 Péroz (2005) 651. 
procedure and thereby part of the minimum standards, the compliance with which is necessary for certification as a European Enforcement Order. ${ }^{28}$ Therefore service pursuant to Article 13(1) shall not be deemed valid in the absence of the acknowledgement of receipt. It is not compulsory to attach the original copy of the acknowledgement of receipt upon certification as a European Enforcement Order, its existence can be evidenced by other means as well. Notwithstanding the acknowledgement, the date is not a fundamental element of the service procedure for as long as it can be evidenced that the document has been served on the debtor. In case the date of service cannot be established due to the lack of date, the document shall be deemed to have been served on the date on which the acknowledgement of receipt has arrived at the court. ${ }^{29}$ The legislative instrument has not provided for the formalities of the acknowledgement of receipt. The reason thereof is that it was not the intention of the legislators to unify the service procedures. As a result, any type of acknowledgement existing in the Member States shall be accepted, provided that it complies with the provisions on content.

Paragraph (2) regulates the case where the summons to a court hearing has not been served on the debtor together with the document instituting the proceedings. ${ }^{30}$ Service thereof can be effected pursuant to any method provided for by Article 13(1). In addition, a summons may have been served on the debtor orally in a previous court hearing on the same claim. This however needs to be stated in a separate minutes. This provision covers the situation in which the debtor participates at the hearing and objects to the claim but subsequently abandons his objection and fails to participate at the second hearing, the date of which was brought to his attention at the previous hearing. ${ }^{31}$

\subsubsection{The internal legislation of Hungary}

In Hungary the document instituting the proceedings shall be lodged with the court by the creditor and the court shall notify the debtor of the document by means of service. The court instruments including the document instituting the proceedings shall be served by means of postal service in general. Service shall be effected pursuant to special rules on service of official documents.

The court shall send an instrument, the receipt of which has legal effects, with an acknowledgement of receipt; upon personal service the person receiving the instrument shall attest the receipt thereof by his dated signature. Where forms are provided for the receipt the receipt should be admitted thereon.

Service with an acknowledgement of receipt: a special postal service available for registered consignments by which the service provider shall have the addressee, or another person entitled to receive it, admit the receipt on the document used for that purpose and shall return the document to the sender or, upon an agreement between the parties, shall provide the sender with the digitised image or the data content of the document by electronic means on a data medium.

The universal postal service provider shall attempt service of an official instrument twice. In case the first service attempt was unsuccessful, the universal postal service provider shall leave behind a notification of the arrival of the official instrument and of the service attempt with an indication determined by the sender, shall keep the consignment at

28 Rauscher (2006) 1524.

29 Rauscher (2006) 1524.

30 Begründung zum Kommisionvorschlag, KOM (2002) 159 endg., 12 zu Art. 14.

31 Begründung zum Kommisionvorschlag, KOM (2002) 159 endg., 12 zu Art. 14. 
the place specified in the notification available for receipt by the entitled person and on the fifth working day following the date of the unsuccessful delivery shall attempt service again. Upon the second unsuccessful service attempt the universal postal service provider shall leave behind a notification for the addressee as indicated on the acknowledgement of receipt. The notification shall include the place and period where and within which the addressee may claim the official instrument. The universal postal service provider shall be obliged to keep the official instrument at the designated place for five working days following the day of the second unsuccessful service attempt.

Court instruments sent by post shall be deemed to have been served on the day on which service was attempted provided that the addressee refused receipt. The latter provision complies with Article 13(1)(b) of the Regulation.

The foregoing rules shall also apply to summons to a court hearing; service of a summons is usually also effected by a postal service provider pursuant to special rules on service of official instruments. There is a special rule for summons due to which in urgent matters summons may be served expeditiously by means of telephony services, electronic mail or special delivery or orally at a hearing. This method of service must have been clearly stated in the documents. Upon postponement of the hearing the court shall forthwith fix the date for a further hearing and communicate this to the parties present through publication, provided that the circumstances of the matter do not preclude the foregoing. In such cases the court usually summons the persons present orally at the hearing.

\subsubsection{Service without proof of receipt by the debtor}

Notwithstanding the methods of service listed in Article 13, Article 14 covers those cases where the instruments are not served on personally the debtor but on other persons or by other methods, however, there is a high degree of likelihood that the debtor shall be notified thereof, as set out in Article 14 of the Preamble as well.

According to the legislator, in case of the methods of service set out in Article 14 the instrument shall be 'within reach' of the debtor who is obliged to perform all that is necessary in order to receive the instrument. ${ }^{32}$ Where service has not been effected in sufficient time, without any fault on the part of the debtor, provisions of Article 19 shall apply.

Article 14 provides for three methods of service: service on a person other than the debtor; deposit of the document in the debtor's mailbox or at a post office or with competent public authorities; by electronic means. All three methods are subject to paragraph (2) according to which the address of the debtor should be known with certainty. There is a risk of misinterpretation of the provisions of Article 13 and 14 since both Articles use the same term (personal service) when in fact it means a different thing in both cases: in the first case the instrument is served personally on the debtor and in the second case on another person, from whom the debtor can claim the instrument however. ${ }^{33}$ As it was already mentioned, the list in Article 14 as regards methods of service is exhaustive and not indicative only. The draft made by the European Parliament recommended an exemplificative list the wording of which would have contained the words 'in particular'. The latter wording would have greatly widened the scope of methods of service which would have been contrary to

32 Begründung zum Kommisionvorschlag, KOM (2002) 159 endg., 11 zu Art. 11-14.

33 Péroz (2005) 652. 
the objective of the Regulation, which is establishing minimum standards for the procedures for uncontested claims. ${ }^{34}$

It is a common characteristic of points (a) to (d) of paragraph (1) that they shall be applied in compliance with the provisions of paragraph (3). The scope of instruments that are subject to service pursuant to the present Article are the same as shown at Article 13.

In the case referred to in point (a) of paragraph (1) personal service of the instruments is effected on persons other than the debtor. The requirements of the Regulation shall have been complied with provided that 'these persons actually received the instruments in question'. ${ }^{35}$ It may be assumed, that where the persons indicated in Article 14 refuse to receive the instruments Article 13(1)(b), which provides for the case where the debtor refuses receipt without any legal justification, shall not be applicable. Therefore the legal consequences of the two acts are also different.

In the proposal made by the Commission the term 'place of domicile of the debtor' was used instead of 'debtor's address'. The latter term appeared in the final version of the Regulation. The risk of assigning different semantic contents by the Member States to the term 'place of domicile' was prevented by dispensing with the term in question. Therefore the term 'debtor's address' was put in the text which means the temporary residence of the debtor. In addition, notwithstanding the original proposal, it is not mandatory for the person receiving the consignment to be of legal age, provided that this person is not the debtor himself. ${ }^{36}$ Dispensing with the latter condition in the final version of the text aims for a simpler wording of the Regulation and simpler provisions as regards methods of service. However, the conditions included in the minimum standards make it necessary for the person served to be capable of giving the instrument to the debtor in order for him to be notified thereof with the highest degree of likelihood.

Article 14(1)(b) governs the case where the debtor is self-employed or a legal person. The category of self-employed includes craftsmen, entrepreneurs and freelancers.

The term personal service is interpreted the same way as in the case covered by point (a) of paragraph (1). According to the interpretation of the Community legislator, the term 'business premises' means the location where the self-employed or legal person permanently performs his activities, such as a store, office, workshop. The scope of the persons employed by the debtor should be interpreted broadly: it includes the debtor's employees (stricto sensu), possible trainees as well as those members of his family who receive no financial reward for their work. ${ }^{37}$ It is not a requirement for the claim at issue to be related to the business premises or activities, claims in connection with the private debts of the debtor can also be served at this location by the method presented above.

Within the meaning of Article 14(1)(c), the minimum standards for service governed by the Regulation have also been fulfilled where the document is deposited in the debtor's mailbox. This method of service carries the same legal consequences as the other methods set out in Article 14, therefore it is not of supplementary nature as compared to the methods set out in points (a) and (b). The Regulation contains no rules on the location of the mailbox as a result of dispensing with the original proposal of the Council ${ }^{38}$ according to which the

34 Kropholler (2005) 609.

35 Stellungnahme der Komission, KOM (2004) 90 endg., 8 zum Erwägungsgrund 11b.

36 Art. 12 I lit.a des Komissionvorschlags, KOM (2002) 159 endg., 25.

37 Kropholler (2005) 610.

38 Art. 12 I lit.c des Komissionvorschlags, KOM (2002) 159 endg., 25. 
mailbox should be at the debtor's address or at his business premises, within the meaning of paragraphs (1) and (2). The clause for the size of the mailbox was also left out, the latter would have ensured the instrument to be deposited safely. A grounds for uncertainty was hereby eliminated according to which the risk of loosing the instrument would have been passed on to the debtor. Such a situation could present itself where the debtor resides in a condominium building and the mailboxes of the residents are not separated from each other therefore everyone can gain access to the instruments in theory. Certain authors ${ }^{39}$ criticize $^{2}$ the differences between the proposal and the final version, which, according to their opinion, in many cases weaken the position of the debtor.

Article 14(1)(d) provides for another method of service, within the meaning of which the instrument can be deposited at a post office or with competent public authorities including the courts. However, in addition to the foregoing, the placing in the debtor's mailbox of written notification of that deposit is mandatory. The written notification must clearly state the character of the document as a court document or the legal effect of the notification as effecting service and setting in motion the running of time for the purposes of time limits.

According to Article 14(1)(e) postal service without proof pursuant to paragraph 3 is sufficient, in contrast to points (a) to (d), provided that the debtor has his address in the Member State of origin. ${ }^{40}$

The Council introduced this easily applicable method of service to the text of the Regulation because hopefully the instrument hereby may be served on the debtor with a high degree of likelihood.

The expectation that the debtor's address should be in the Member State of origin is slightly unclear ${ }^{41}$ because the wording differs in the different languages (in English for example they speak of his address while in French it is 'a' address, i.e. 'his address' and 'une adresse'). The problem, that has also presented itself in relation to point (a) as regards the debtor's address and point (b) as regards 'business premises', i.e. whether this exists or was only invented by the creditor, hereby arises. The court has competence to resolve this matter.

Article 14(1)(f) provides for another method of service which is effected by electronic means attested by an automatic confirmation of delivery.

Notwithstanding notification by fax or e-mail provided for by Article 13(1)(d) this method of service does not require a signed and dated acknowledgement of receipt to be returned by the debtor to the sender. A further relaxation has been introduced by the legislator according to which attestation of the served instrument pursuant to Article 14(3) is unnecessary. In this case electronic means covers fax and e-mail. An automatic confirmation of delivery is not the same as an acknowledgement of receipt. In case of service by fax the function of automatic confirmation of delivery of the fax machine is sufficient proof, while in case of an electronic mail this is evidenced by the server of the sender. It is a precondition of this method of service that the debtor has expressly accepted it in advance. The debtor can accept the methods in general, it is not necessary for him to

39 Stadler (2004) 806.

40 Article 4(4) establishes that the Member State of origin means the Member State in which the judgment has been given, the court settlement has been approved or concluded or the authentic instrument has been drawn up or registered, and is to be certified as a European Enforcement Order.

41 Stadler (2004) 806. 
name a certain method of service. There are no required formalities as regards the acceptance by the debtor. ${ }^{42}$

Within the meaning of paragraph (2) service effected pursuant to paragraph (1) cannot be accepted where the debtor's address is not known with certainty. This wording clearly shows that a method of service that is based on legal fiction shall not be allowed by the Regulation . As a result thereof, the national legislation of the Member States that deem service effected where the debtor's address is unknown, for example by public notification, shall not comply with the minimum standards, therefore, pursuant to its application, certification of the judicial decision as a European Enforcement Order shall not be possible.

Service of an instrument pursuant to point (a) to (d) of paragraph 1 requires an additional condition to be fulfilled. This condition shall be the attestation by the competent person effecting service that service has been effected. This can be performed by signing an instrument that must have contained the elements listed in point (a) of paragraph (3). Service effected within the meaning of points (a) and (b) of paragraph (1) shall be attested by an acknowledgement of receipt completed by the notified person. Attestation by the competent person effecting service is not a formality of service but the only means of proof that the addressee received the instrument. The fact of service can only be attested by the signature of the person concerned. In the absence of such an attestation an instrument cannot be certified as a European Enforcement Order not even where the fact of service can be evidenced by other means. ${ }^{43}$ In case this attestation is lost, the fact of service cannot be attested by any other method since it is not an element of the service but a means of proof in itself.

The Regulation contains no requirements as regards the content of the acknowledgement of receipt provided for by point (b) of paragraph (3). For reasons of rationality, the conclusion can be drawn from the similarity with the wording of Article 13 that the same rules on content shall apply to this case as to the cases provided for by the foregoing paragraphs. An acknowledgement of receipt completed pursuant to Article 14(3)(b), which acknowledgement substitutes the attestation signed by the competent person effecting service, must have contained the elements set out in point (a) in order to fulfil its purpose. ${ }^{44}$

The provisions included in Article 14 are regarded as the Achilles heel of the European Enforcement Order since the 'high degree of likelihood' presumed by the Preamble cannot be found in the referred provisions and the system blindly trusts the person who receives the document or removes it from the mailbox..$^{45}$

Service pursuant to Regulation may also have been effected on a debtor's representative.

\subsubsection{The internal legislation of Hungary}

In Hungary the document instituting the proceedings and the summons to a court hearing shall be communicated to the defendant by the court by means of service. Service of court instruments shall usually be effected by a postal service provider, pursuant to special rules on service of official documents.

The Hungarian legislation contains special rules as regards those cases where service is not effected on the debtor's own hands.

42 Kropholler (2005) 613.

43 Rauscher (2006) 1532.

44 Rauscher (2006) 1532.

45 Péroz (2005) 653. 
The universal postal service provider shall attempt service of an official instrument twice. In case the first service attempt was unsuccessful, the universal postal service provider shall leave behind a notification of the arrival of the official instrument and of the service attempt with an indication determined by the sender, shall keep the consignment at the place specified in the notification available for receipt by the entitled person and on the fifth working day following the date of the unsuccessful delivery shall attempt service again. Upon the second unsuccessful service attempt the universal postal service provider shall leave behind a notification for the addressee as indicated on the acknowledgement of receipt. The notification shall include the place and period where and within which the addressee may claim the official instrument. The universal postal service provider shall be obliged to keep the official instrument at the designated place for five working days following the day of the second unsuccessful service attempt.

Where service was unsuccessful due to the refusal of receipt of the document by the addressee, i.e. the document was returned to the court as 'unclaimed', the document, in the absence of evidence to the contrary, shall be deemed to have been served on the fifth day following the second attempt of postal service.

Upon service of the document instituting the proceedings or the judgment on the substance ending the proceedings the court shall notify the parties that the presumption of service being effected has been established within eight working days. The official document upon which the presumption of service being effected has been established by the court shall be attached to the notification. The addressee can claim the document meant for him at the court bureau upon proving his identity.

Where the natural person addressee is not present at the place indicated in the address at the time of service and neither is his representative, service can be effected on the following persons (alternate receiver) who are present there, unless excluded by the addressee:

(a) a close relative of no less than 14 years of age of the addressee,

(b) the lessor or lodger of the addressee, in case of a natural person.

The alternate receiver must indicate, besides his signature, on the document attesting service the legal grounds for his entitlement to receive the document and, in case of domestic service of a foreign official document, his name and address as well. In case doubt arises in the service provider in connection with the existence of such title, the service provider may require that the title be attested by means of an authentic instrument. In the absence of such attestation the service provider places a written notification of the arrival of the consignment in the debtor's mailbox.

Upon service effected at a post office, a person shall be deemed an alternate receiver if he attests, by means of an official instrument presented at the time of receipt, that his address is the same as the one indicated on the consignment.

According to Hungarian law, in certain cases, such as the temporary residence of the party is unknown or is in a State that offers no assistance for service, or by reason of force majeure, service shall be effected by public notification. Public notification provided for by the Hungarian Code of Civil Procedure does not comply with the minimum standards included in the Regulation because it is based on a legal fiction.

\subsubsection{Regulation no. 861/2007/EC and Regulation no. 1896/2006/EC}

Regulation no. 861/2007/EC essentially refers back to the above mentioned rules of Regulation no. 805/2004/EC in respect of the service of documents and provides for their application, while Regulation no. 1896/2006/EC also repeats the content of Regulation no. 805/2004/EC. 


\subsection{The provision of adequate information}

\subsubsection{The provision of adequate information according to Regulation no. 805/2004/EC}

The second group of the minimum standards of Regulation (EC) No 805/2004. contain rules on the provision to the debtor of due information. ${ }^{46}$ The objective of this scheme, as it can likewise be seen under the introductory provisions, is to ensure that the debtor is duly informed about the names and addresses of the parties, the amount of the claim, the interests and the reason for the claim. ${ }^{47}$ These provisions result from the rationality that without these pieces of information the debtor cannot decide how to arrange for his defence or whether he shall arrange for his defence at all, with special regard to the risks and legal consequences that a possible passive conduct entails.

Similarly to Article 13, the provisions of Article 16 shall only be applicable with regard to the provisions of Article 13(1)(b) and (c) and cannot be applied as regards Article 3(1)(a) and (d). These latter provisions govern those cases where the debtor has expressly agreed to the claim by admission or by means of a settlement which has been approved by a court or concluded before a court in the course of proceedings or by means of an authentic instrument.

The information listed in points (a) to (d) of the present Article have to be indicated on the document instituting the court proceedings or an equivalent document and cannot be the subject of another document. In case of a document instituting the court proceedings or an equivalent document provisions of Article 13 to 15 shall apply.

The elements included in point (a) to (d) cannot be relativised: the debtor must be informed thereof even if he already was in possession of these pieces of information, otherwise certification as a European Enforcement Order can be refused. The scope of these elements cannot be extended by the Member States. ${ }^{48}$ A judgment can be certified as a European Enforcement Order even where the document instituting the court proceedings has not contained all information requested by national legislation, provided that the provisions of Article 16 have been met. However, such an omission may be grounds for a challenge against the judgment to be initiated.

The document instituting the court proceedings must have contained the value of the claim as well, besides the names and addresses of the parties. It is mandatory to indicate the name and address of the debtor and creditor but not of the representatives. The value of the claim shall be set as a specific, quantified amount. The purpose of this regulation is provision to the debtor of due information. ${ }^{49}$ While drafting the document instituting the court proceedings the minimum standards shall be complied with in respect of the claim. ${ }^{50}$ If interest on the claim is sought, the debtor shall be provided with information on the interest rate and the period for which interest is sought as well, within the meaning of point (c). The case where statutory interest is automatically added to the principal under the internal legislation of the Member State of origin is an exception to this rule. By determining this exception such situations were intended to be prevented where certification as a European Enforcement Order were to be cancelled on the grounds that the creditor has

46 Gyekiczky et al. (2007) 176.

47 Harsági, (2006) 8.

48 Rauscher (2006) 1535.

49 Harsági (2005) 27.

50 Rauscher (2006) 1536. 
failed to indicate the data on the interest in the document instituting the court proceedings although the court has to decide on this issue as well, according to the law.

Provisions of point (d) on the reason for the claim were included during the development of the Regulation. The first version of the draft made by the Council contained the following: 'presentation of the subject of the claim, including a brief description of the facts'. ${ }^{51}$ The wording 'a statement of the reason for the claim is necessary' subsequently appeared in the draft of the Council, amended in 2003. ${ }^{52}$ The wording included in the final version is intended to allow for "presentation of the reason for the claim shall fulfil the conditions of certification as a European Enforcement Order similarly to the method governed by summary proceedings concerning orders to pay'. ${ }^{3}$ The Council has not introduced new terms during the drafting that would make the understanding and application thereof more difficult but, on the contrary, aimed for simplification in order to avoid any confusion in interpretation. Consequently: a brief description of the facts or the grounds for the claim, as required by the previous version, is unnecessary, instead, statement of the reason for the claim, that ensures provision to the debtor of due information, shall be sufficient.

In Hungary the document instituting the proceedings (statement of claim, orders to pay) contains all elements required by Article 16 of the Regulation.

The following must have been clearly stated in the statement of claim: names of the parties and the representatives, their place of domicile and capacity in the litigation; the right intended to be enforced and the presentation of the facts and proofs on which it is based; the data upon which the competence and jurisdiction of the court can be established; an explicit request for a decision by the court (claim).

The rules on the statement of claim shall apply to the contents of the claim for issuing an order for payment. The order for payment issued by the notary and served on the debtor must have also contained the following: the notary seised of the proceedings and the case number; names and places of domicile, temporary residence or seat, of the parties and the representatives; the reason for the claim and the amount of the claim; the order, according to which the debtor is required to satisfy the claim within 15 days from the date of service, and pay the quantified costs related to the proceedings; provision of information about the fact that the notary has not examined the reason for the claim and the facts which serve as proof thereof as to their substance and that the order shall become final and executable if the debtor fails to object within the time limit; a warning, according to which the debtor may object to the order, in case he finds the claim unsubstantiated; a warning, that fulfilment of the claim by the debtor, after having received the order, shall amount to admission of the claim and the order shall become final on the day following the last day of the time limit for objection.

The purpose of the provisions of Article 17 is to guarantee that a judgment will not be certified as a European Enforcement Order where the debtor was not provided with information in the course of the court proceedings on the necessary procedural steps to contest the claim, or on the consequences of his passive conduct, which may take the form of an absence of objection or default of appearance. Consequently: all Member States need to coordinate their law of civil procedure with the requirements included in the Regulation

${ }^{51}$ KOM (2002) 159 endg., 27 (Art. 16 lit.d).

52 KOM (2002) 159 endg., 27 (Art. 16 lit.d).

53 Stellungnahme der Komission, KOM (2004) 90 endg., 5 unter 3.2.1.2: Abänderung 14 (Art. 16 lit. d des Vorschlags). 
so that the judgments given by the courts of the Member States can be certified as a European Enforcement Order.

We find information about the method of provision of information in the introductory part of the Article: the debtor shall be provided with information by or together with the document instituting the proceedings, the equivalent document or any summons to a court hearing.

In spite of the alternative list, the efficiency of the provision of information has to be taken into consideration as well, since provision of information in the document instituting the proceedings shall supersede subsequent methods of provision of information. It can be seen from the analysis of the listed instruments that provision to the debtor of information in writing is mandatory, ${ }^{54}$ regardless of the fact whether such provision of information has been effected by the court or the creditor, or whether the court has effected service. The absence of provision to the debtor of due information shall entail the legal consequences that the delivered judicial decision cannot be certified as a European Enforcement Order.

The legislation does not cover the aspects of the language of provision of information, therefore the legislation on service shall apply to the provision to the debtor of information, including the aspects of language as well. Regulation (EC) No 1393/2007 of the European Parliament and of the Council on the service in the Member States of judicial and extrajudicial documents in civil and commercial matters ('service of documents') and repealing Council Regulation (EC) No 1348/2000 regulates language issues as well. Within the meaning of Article 8 the addressee may refuse to receive the instrument to be served upon service or may return the instrument within one week from the day of service where the instrument has not been drawn up in one of the following languages and no translation has been attached thereof: (a) a language the addressee understands; or (b) the official language of the Member State or, if there are several official languages in that Member State, the official language or one of the official languages of the place of service.

The absence of clarification of the aspects of language may entail a number of difficulties during application, in particular, with regard to the consequences of the passive conduct of the debtor, especially in the case where the debtor has never objected to the claim or appeared at the hearing because he was unfamiliar with the language of the notification and judgment is given. The debtor hereby may be put in a disadvantageous position, because the judgment, if it has been certified as a European Enforcement Order, cannot be subject to review in the Member State of enforcement pursuant to Article 21(2). ${ }^{55}$

This opinion is shared by Rauscher as well, ${ }^{56}$ who regrets that the provisions of Article 8 of Regulation (EC) No 1393/2007 ${ }^{57}$ have not been incorporated into the text of the present Regulation, therefore service to another Member State shall be effected pursuant to the legislation of the Member State of origin.

During the critical analysis of Regulation (EC) No 805/2004 Dr. Astrid Stadler ${ }^{58}$ indicates the silence of the Community legislator as regards the issue of the language and translation of the instruments that are subjects to the service procedure as well as the

54 Rauscher (2006) 1538.

55 Stadler (2004) 807.

56 Rauscher (2006) 1539.

57 Regulation (EC) No 1393/2007, which regulates the service of judicial and extrajudicial documents in civil and commercial matters ('service of documents') and repeals Council Regulation (EC) No 1348/2000 OJ L 324, 10/12/2007., 0079-0120.

58 Stadler (2004) 807. 
information procedure. The Regulation does not include any provision on the language of the document instituting the court proceedings or of the provision of information about the consequences of default of appearance of the debtor. According to the author's opinion which is delivered by examples, failure to govern this issue could seriously harm the rights of the debtor. Rauscher shares this opinion ${ }^{59}$ and criticizes the Community legislator for its failure to govern these questions concerning language because understanding an instrument that has been drawn up in a certain language could cause difficulties for one party, especially the debtor, as a result of such omission. In case the documents served were issued in a language incomprehensible to the debtor then, although the minimum standards have been formally fulfilled, the debtor may be put into a disadvantageous position. It would have been reasonable to this end to include the provisions on language, as regards the language of the documents served and the provision of information, among the minimum standards so that the rights of the defence of the debtor would be guaranteed. ${ }^{60}$

The procedural requirements, which are mandatory and must be complied with in case of an objection to the claim and which are the subject of the obligation of provision to the debtor of due information, are listed under point (a). The following must have been clearly stated: (1) the time limit for contesting the claim in writing or the time for the court hearing, as applicable; (2) the name and the address of the institution to which to respond or before which to appear, as applicable; and (3) whether it is mandatory to be represented by a lawyer. The term 'including' indicates that the list is not exhaustive. ${ }^{61}$ It can be established pursuant to the list under the present Article, that statement of only the most important elements was intended, which can generally influence the possibility to object to the claim. Where the national procedure rules include other mandatory requirements as well, the obligation of provision of information shall apply also apply to them.

Provision to the debtor of information shall also be obligatory where it is mandatory to be represented by a lawyer. It is problematic to decide, whether it is mandatory to provide the debtor with information if the procedure rules fail to govern this obligation, with regard to the objectives of the Regulation, i.e. protection of the rights of the debtor. ${ }^{62}$

Point (b) contains, under 'in particular', the legal consequences resulting from the passive conduct of the debtor, which conduct can take the form of an absence of objection or default of appearance: a court decision can be given against him, an enforcement procedure can be initiated against him and he can be obliged to bear the costs related to the court proceedings. The wording of the text of the Regulation is simpler and more strict than that of the first version of the draft proposed by the Council. ${ }^{63}$ According to the draft, the court could entirely or partially disregard the circumstances on which the claim was based in the course of delivery of the judgment in favor of the creditor. ${ }^{64}$

At the same time, it is not a subject of the obligation to provide the debtor with due information to describe the consequence that the judgment can be certified as a European Enforcement Order. This option was included in the first version of the draft. ${ }^{65}$ This

59 Rauscher (2006) 1517.

${ }^{60}$ Kapa and Veress (2009) 194.

${ }^{61}$ On this subject see the German text ('insbesondere', which could be translated as 'in particular'), which better reflects the intention of the legislator.

62 Rauscher (2006) 1539.

63 Kropholler (2005) 618.

${ }^{64}$ Stellungnahme der Komission, KOM (2004) 90 endg., 10 unter 3.2.2. zu Art. 17 und 18.

65 Art. 17 lit.e, KOM (2002) 159 endg., 28. 
provision was subsequently deleted from the text of the Regulation; the provisions of point

(b) concentrate on the consequences governed by the Member State of origin (lex fori).

According to Hungarian law, the document instituting the proceedings and the related summons basically contain what is required by Article 17 .

The summons must have contained the court seised of the proceedings and the case number, the name and the capacity in the litigation of the parties, as well as the date and place fixed for the hearing. The addressee has to be warned in the summons of the consequences of default of appearance, and he also has to be provided with due information according to his capacity in the litigation anyway. The parties shall be warned in the summons to the hearing that, in case they fail to appear at the hearing in person, they may only be represented by a person determined by law. A copy of the statement of claim (or a copy thereof) shall be attached to the summons to the first hearing, in case it has not yet been served. The parties shall be requested by the summons to bring the instruments related to the claim with them to the hearing and the debtor shall be warned, that no later than at the hearing, he shall be required to reflect on the claim and describe the facts and proof that serve as grounds for his defence and also to present his documents on the claim. The summons shall also indicate that the debtor may submit his declaration or have it recorded in the minutes before the fixed date.

The Hungarian Code of Civil Procedure, as regards the contents of the judgments, requires that the decree provides information about the possibility to appeal the decree, and to where and within what time such an appeal should be submitted, following the operative part of the judgment. This rule shall also apply to orders.

In summary proceedings concerning orders to pay the debtor becomes aware of the proceedings against him at the time of the order to pay being served on him. The order to pay must have contained, inter alia, provision of information about the fact that the court has not examined the reason for the claim and the facts which serve as proof thereof as to their substance and that the order shall become final and executable if the debtor fails to object within the time limit; as well as a warning, according to which the debtor may object to the order in case he finds the claim unsubstantiated.

In case the defendant has missed the first hearing and has not arranged for his defence as to substance, a special condemnation, a court order, may be issued against him. The court order served on the defendant must have contained the statement of the court and case number, the mandatory provision on payment of the costs related to the court proceedings, and, if appropriate, statement of preliminary enforceability, the warning on the possibility of objection, and finally, it should be indicated that a final court order has the same effect as the decree.

\subsubsection{The content of documents instituting civil proceedings according to Regulation no. 861/2007/EC and Regulation no. 1896/2006/EC}

While in case of national procedures regulated by laws of the member states, national regulations define both the formal and content related requirements of documents instituting the case, in case of sui generis European procedures the supranational regulation effective in all member states regulates the issue of documents instituting the procedure.

Regulation (EC) No. 1896/2006 regulates the European order for payment procedure. This procedure can be instituted in any member state of the European Union by using the form attached to the regulation in the annex. The application shall include:

- the names and addresses of the parties, and, where applicable, their representatives, and of the court to which the application is made; 
- the amount of the claim, including the principal and, where applicable, interest, contractual penalties and costs;

- if interest on the claim is demanded, the interest rate and the period of time for which that interest is demanded unless statutory interest is automatically added to the principal under the law of the Member State of origin;

- the cause of the action, including a description of the circumstances invoked as the basis of the claim and, where applicable, of the interest demanded;

- a description of evidence supporting the claim;

- the grounds for jurisdiction;

- the cross-border nature of the case.

The European small claims procedure is regulated by regulation (EC) No. 861/2007. Here too the annex of the regulation includes the claim form to be used to institute the procedure. The latter one is the sample of a claim instituting a litigious procedure. It shall include the proceeding court, the data of both the claimant and the defendant, the jurisdiction, the cross-border nature of the case, the amount of the claim, including the principal and, where applicable, interest and costs, a description of evidence supporting the claim, a special request to hold a trial, and where applicable a request for a certificate for recognition and enforcement the judgment in a Member State other than that of the court.

A uniform application or claim form instituting procedures exists in both the European order for payment procedure and the European small claims procedure. These two types of application forms basically contain all the elements necessary for the defendant (debtor) to ponder on the well-foundedness of the claim brought against him and decide on what procedural steps to take. This also means that one of the possible methods of providing adequate information is to unify the content of documents instituting proceedings by way of introducing application forms at least in cross-border cases.

\section{CONCLUSIONS}

The article presented the most important Hungarian and European Union pieces of legislation regarding the service of documents instituting civil proceedings. Based on the above, the following main conclusions can be drawn.

a) The rules on the service of documents instituting civil proceedings and on the provision of adequate information to the defendant primarily protect the defendant's interests and seek to guarantee the defendant's right to a fair trial. However, these rules may sometimes make it difficult for the plaintiff to enforce his lawful claim.

b) The documents instituting proceedings have to be successfully served, at least in terms of procedural rules, on the addressee in order for the court to continue its proceedings. Therefore it is particularly important to determine when the service of documents should be deemed successful in terms of the applicable procedural rules.

c) Special problems may arise if the documents instituting civil proceedings have to be served in a country other than the one in which proceedings are to be launched: litigants may encounter serious challenges due to the different languages and procedural regimes of the countries concerned.

d) The European Union's Member States have different national legislation regarding the service of documents instituting civil proceedings and the provision of adequate information to the defendant. For instance, the direct service of documents, the legal fiction of service and the extent of the provision of information to the defendant are interpreted in diverging ways by the different Member States. 
e) With regard to the foregoing, the European Union harmonised the service in the Member States of judicial and extrajudicial documents in the past years. Firstly, the European Union elaborated a regulation on the cross-border service of documents, secondly, it set certain minimum standards for the Member States in respect of some supranational procedures.

f) An additional development goal could be the general standardisation of the rules on the service of documents instituting civil proceedings and on the provision of adequate information to the defendant. The author of the present article is of the opinion that such standardisation would require very careful preparations as well as comparative legal studies that should be much more thorough than the ones carried out for the preparation of the harmonisation of the Member States' procedural laws. The following short story perfectly illustrates the risks of a too rapid standardisation:

As the ancient oriental tale goes, one day a turtle was swimming in a lake. While swimming it kept repeating to itself: 'Thank God I'm so slow, thank God, I'm so slow'. A bird was flying that way and heard the turtle's words. The bird asked the turtle: 'Why are you thanking God that you are so slow?' 'Because I'm swimming in the wrong direction' the turtle replied.

\section{LITERATURE}

Gyekiczky, T., Kormos, E., Köblös, A., Molnár, J., Nagy, A., Wallacher, L. and Wopera, Zs., $A z$ Európai Unió polgári eljárásjoga (The European Union's civil procedural law) (Complex 2007).

Harsági, V., ‘A nem vitatott követelések végrehajtása az Európai Igazságügyi Térségben' (The enforcement of uncontested claims in the European judicial area) (2005) 6 Európai Jog 23-29.

Harsági, V., 'A közjegyzöi okiratok végrehajtása az európai Unióban a 44/2001/EK rendelet és a 805/2004/EK rendelet tükrében' (The enforcement of notarial acts in the European Union in the light of Regulation 44/2001/EC and Regulation 805/2004/EC) (2006) 11-12 Közjegyzők Közlönye 3-8.

Kapa, M., and Veress, E. (eds), Enforcement of Judgments in civil and commercial matters in crossborder cases in the European Union. (KGRE 2009).

Kengyel, M., and Harsági, V., Európai polgári eljárásjog (European civil procedural law) (Osiris 2009).

Lindacher, W., 'Europäisches Zustellungsrecht - Die VO (EG) nr. 1348/2000: Fortschritt, Auslegungsbedarf, Problemusblendung' (2001) 114 ZZP 179-94.

Stadler, A., 'Neues Europäisches Zustellungsrecht' (2001) 21 IPrax 514-20.

Oberhammer, P., 'Der Europäische Vollstreckungstitel: Rechtpolitische Ziele und Methoden' (2006) 8 Juristische Blätter 479-81.

Péroz, H., 'Lé réglement CE n̊805/2004 du 21 avril 2004 portant création d'un titre exécutoire européen pour les créances incontestées.' (2005) 3 Journal du Droit International 650-53.

Rauscher, T., Europäisches Zivilprozeßrecht ( $2^{\text {nd }}$ edition, European Law Publishers 2006).

Stadler, A., 'Kritische Anmerkungen zum Europäischen Vollstreckungstitel' (2004) 11 Recht der Internationalen Wirtschaft 806-07.

Stein, A., 'Der Europäische Vollstreckungstitel für unbestrittene Forderungen - Einstieg in den Ausstieg aus dem Exequaturverfahren bei Auslandsvollstreckung' (2004) 22 EuZW 679-82.

Storskrubb, E., Civil procedure and EU Law, A policy area uncovered (OUP 2008).

Wagner, R., 'Der Europäische Vollstreckungstitel' (2005) 17 Neue Juristische Wochenschrift, 1157160. 